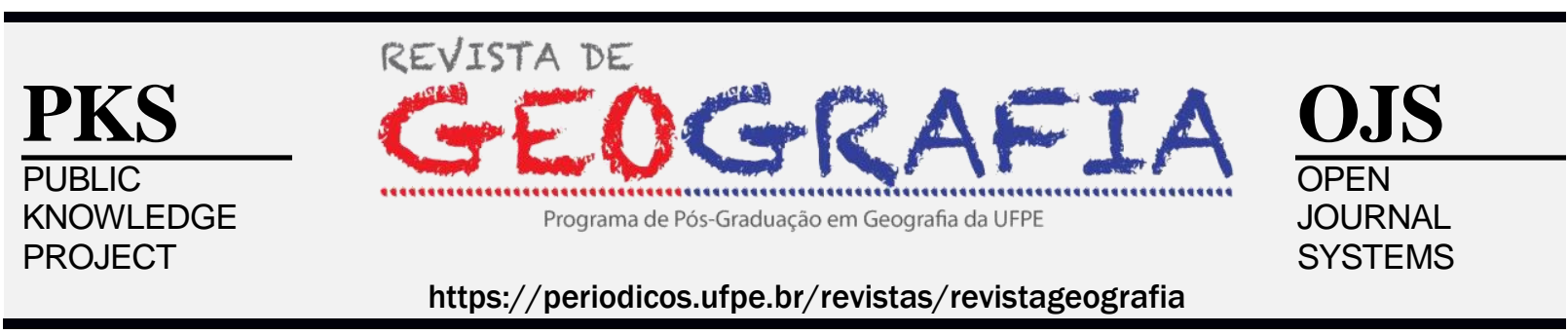

\title{
FINCANDO AS RAÍZES DO RENTISMO À BRASILEIRA: OS RURALISTAS NA ASSEMBLEIA NACIONAL CONSTITUINTE (1987-1988)
}

\author{
Gustavo Francisco Teixeira Prieto ${ }^{1}$ \\ ${ }^{1}$ Professor Adjunto do Instituto das Cidades da Universidade Federal de São Paulo (Unifesp). E-mail: \\ gustavo.prieto@unifesp.br
}

Artigo recebido em 27/03/19 e aceito em 19/05/19

\begin{abstract}
RESUMO
Partindo da problemática da questão agrária brasileira, este artigo analisa os arranjos jurídicos e a luta de classes decorrentes das propostas, da tramitação e dos conflitos referentes à reforma agrária, à propriedade privada, à desapropriação e à função social da terra na Assembleia Nacional Constituinte (ANC) de 1987-1988. A reflexão em tela problematiza três processos político-territoriais na década de 1980 que simultaneamente são fundamentos e formas de reprodução do rentismo à brasileira na história contemporânea, quais sejam: i) as estratégias de bloqueio à reforma agrária pelos grandes proprietários de terra associadas à manutenção da grilagem de terras na transição liberal da ditadura militar; ii) os conflitos, as propostas e as lutas ideológicas (e territoriais) sobre a constitucionalização da reforma agrária brasileira na ANC e iii) a organização política dos ruralistas a partir de entidades patronais e do Centrão com o intuito de manter a estrutura fundiária, de riqueza e poder sem alterações na Constituição de 1988.
\end{abstract}

Palavras-chave: reforma agrária; concentração fundiária; latifúndio; Assembleia Nacional Constituinte; Constituição.

\section{SETTING THE ROOTS OF BRAZILIAN RENTISM: THE RURALISTAS OF THE NATIONAL CONSTITUENT ASSEMBLY (1987-1988)}

\begin{abstract}
This article analyzes the legal arrangements and the class struggle resulting from the proposals, procedures and conflicts related to agrarian reform, private property, expropriation and social function of land during the National Constituent Assembly (ANC) of 1987-1988. The article problematizes three political-territorial processes in the decade of 1980 that at the same time are foundations and forms of reproduction of Brazilian rentism in the contemporary history, which are: i) strategies for blocking land reform by large landowners associated with the maintenance of illegal land grabbing in the liberal transition of the military dictatorship; ii) conflicts, proposals and ideological (and territorial) struggles over the constitutionalisation of the Brazilian agrarian reform in the ANC; and iii) the political organization of the "ruralistas" from employers and the "Centrão" with the intention of maintaining the land structure, of wealth and power without changes in the Constitution of 1988.
\end{abstract}

Keywords: Agrarian Reform; Land Concentration; Latifundio; National Constituent Assembly; Brazilian Constitution.

Prieto, 2019

ISSN 0104-5490 


\section{INTRODUÇÃO}

Em $1^{\circ}$ de fevereiro de 1987 iniciaram-se as atividades da Assembleia Nacional Constituinte (ANC) atendendo a Mensagem n. 48 de 28 de junho de 1985 e a convocação da Emenda Constitucional n. 26 de 27 de novembro de 1985. Os 559 parlamentares eleitos por pleito geral realizado em 15 de novembro de 1986 tinham a atribuição de produzir uma nova Constituição para o Brasil.

A ANC se instalou no Congresso Nacional atravessada pelos 21 anos de repressão, violência e autoritarismo da ditadura civil-militar, pela derrota da campanha para a realização de eleições diretas para a Presidência da República em 1984 (as Diretas Já) e transcorridos quase dois anos do governo José Sarney, vice-presidente escolhido indiretamente pelo Congresso e umbilicalmente ligado à ditadura, que assumiu o poder político em decorrência da morte de Tancredo Neves.

O então presidente do Supremo Tribunal Federal (STF), o ministro José Carlos Moreira Alves, que havia sido procurador-geral da República no governo do ditador-general Emílio Garrastazu Médici foi responsável pela instalação da ANC no Congresso Nacional, pela sessão de eleição da Mesa Diretora (com a presidência ficando a cargo do deputado constituinte Ulysses Guimarães - PMDB-SP) e pelo discurso de abertura. Gomes (2013, p. 136, grifo nosso) retomou a fala lapidar do ministro, misto de tragédia e farsa, que mobilizou o artigo em tela:

Ao instalar-se esta Assembleia Nacional Constituinte, chega-se ao termo final do período de transição com que, sem ruptura constitucional e por via de conciliação, se encerra ciclo revolucionário.

O discurso de Moreira Alves revela como parte expressiva do Poder Judiciário brasileiro, inclusive em seus altos cargos, refletia - e ainda reflete - sobre a história e a política no período entre 1964 e 1985. Simultaneamente, auxilia-nos a descortinar a aparência de neutralidade ou imparcialidade de parte expressiva dos juristas brasileiros na ditadura civilmilitar. Além disso, a narrativa discursiva do presidente do STF retratava a ditadura produzida pelos militares brasileiros e apoiada em perspectiva de classe, sobretudo pela burguesia nacional, pelos latifundiários e pelas empresas multinacionais como um "ciclo revolucionário" e não um golpe de Estado.

O termo "conciliação" ressaltado no discurso, conforme argumentaram Gomes (2013) e Gomes da Silva (1989), revelava as perspectivas do que o ministro-jurista e também parte 
expressiva dos militares, da burguesia brasileira, do capital internacional e dos latifundiários esperavam da Carta Constitucional. Trocando em miúdos, significava aceitar parcialmente e lateralmente algumas reformas, mas manter o pacto político-territorial e econômico-social fundamentado pela aliança das classes dirigentes brasileiras forjado na ditadura e articuladamente controlar e centralizar sob tutela militar o processo de transição para a democracia liberal. Conciliação também a fim de escamotear as contradições de classe e as divergências entre os projetos políticos das elites aliançadas e os interesses das organizações e movimentos sociais camponeses, indígenas e sindicais em ascensão.

Para Quartim de Moraes (1982) e Codato (2005) o objetivo estratégico do processo de reconversão liberal do regime militar sob tutela das Forças Armadas foi a institucionalização jurídica, política e social de uma série de dispositivos autoritários que, depois de encerrado o assim chamado ciclo dos generais, garantissem legitimidade, estabilidade e funcionalidade a um novo modelo político que não fosse nem "populista", nem plenamente "democrático". Para Fontes (2010) se estabelecem na década de 1980 no Brasil os fundamentos liberais do Estado seletivo em uma sociedade truculenta, constitucionalizando uma série de violências de Estado, limitando o processo democrático a uma sociedade mercantil-filantrópica e restringindo ao máximo a universalidade de direitos conquistados pelas lutas sociais.

O objetivo do presente artigo, então, é analisar três processos político-territoriais brasileiros na década de 1980, centrais para a questão agrária, que simultaneamente são fundamentos e formas de reprodução do rentismo à brasileira na história contemporânea, quais sejam: i) as estratégias de bloqueio à reforma agrária pelos grandes proprietários de terra e a manutenção da grilagem de terras na transição liberal da ditadura militar; ii) os conflitos, as propostas e as lutas ideológicas (e territoriais) sobre a constitucionalização da reforma agrária brasileira na ANC e iii) a organização política dos ruralistas a partir de entidades patronais e do Centrão com o intuito de manter a estrutura fundiária, de riqueza e poder sem alterações na Constituição de 1988. A reprodução da aliança de classes entre burguesia urbana-industrial e proprietários de terras foi fortemente sedimentada com os conflitos sociais, políticos e econômicos estabelecidos na produção da Carta Constitucional. Apesar de alguns pontos progressistas para a questão agrária, o ano de 1988 representa o rebaixamento de expectativa de alterações profundas na estrutura fundiária e no poder social e econômico dos latifundiários e a consolidação do ruralismo como principal força política do Congresso Nacional. 


\section{REFORMA AGRÁRIA: A “CONCILIAÇÃO” RENTISTA DOS GRANDES PROPRIETÁRIOS DE TERRA}

Durante a ditadura civil-militar brasileira a grande propriedade capitalista da terra foi produzida sob o auspício e condescendência do aparelho do Estado e do poder judiciário com o aprofundamento vertiginoso da grilagem legalizada de terras, de uma contrarreforma agrária fundamentada no reforço ao caráter absoluto da propriedade privada capitalista, de uma política de modernização da agricultura baseada em incentivos fiscais (que institucionalizou e, de imediato, rotineirizou a aliança entre capitalistas urbano-industriais e latifundiários), do avanço da frente de expansão econômica para a Amazônia Legal e da venda de terras para estrangeiros (MARTINS, 1994; OLIVEIRA, 2007; PRIETO, 2017a).

Ianni (1979) enfatizou que a grilagem não era uma entre outras modalidades de aquisição de terras na ditadura civil-militar brasileira. A grilagem foi a mais importante estratégia de acumulação e produção de capital, pois frequentemente se associou a processos de compra e venda de terras. Em outras palavras, sistematicamente a grilagem se mesclou com outras modalidades de aquisição de terras, sendo que, em inúmeros casos, era impossível distingui-las. O grilo se realizava, em inúmeros casos, sobre uma fina camada juridicamente legal de aquisição formal da terra acompanhada diretamente de ampla dominação privada e ilegal de patrimônio público (ou de terra comunal, coletiva, camponesa ou de posses) como estratégia de expansão territorial. A grilagem de terras reafirmou-se na ditadura como a forma per se de aquisição fundiária no Brasil, o que contribuiu peremptoriamente para as atuais e dramáticas estatísticas que revelam que há entre 100 e 300 milhões de hectares de terras (de um total de cerca de 851 milhões de hectares) com fortes indícios de grilagem (BRASIL, 1999; BRASIL, 2001; OLIVEIRA, 2011a).

Nesse sentido, Ianni (1979, p. 167) afirmou que "a falsificação e a veracidade de documentos e evidências e testemunhas mesclam-se" pela associação entre "grileiros, empresários, advogados, funcionários e outros". Oliveira (2011a; 2011b), ao analisar o cadastro do INCRA em 2003, verificou que existiam mais de 67 milhões de hectares de terras devolutas na Amazônia. O Censo Agropecuário de 2006 revelava que existiam no Brasil mais de 310 milhões de hectares de terras devolutas ${ }^{1}$. Entretanto, parte expressiva delas, apesar de

\footnotetext{
${ }^{1}$ Oliveira (2008) argumenta, a partir dos dados disponíveis no INCRA, que em 2003 a área ocupada por terras públicas devolutas era superior a 400 milhões de hectares, ou seja, praticamente metade da extensão territorial do Estado brasileiro. O geógrafo enfatiza que mais de 200 milhões dessas terras não estavam sequer cadastradas pelo órgão.
} 
terras públicas, foi cercada pelo poder dos grileiros-proprietários de terra, sobremaneira no regime militar.

Constata-se que na ditadura civil-militar produziu-se uma aliança de classes entre capitalistas urbanos e latifundiários que fundamentou um projeto político de cunho eminentemente oligárquico dissimulado de modernidade, de desenvolvimento do capitalismo assentado na dominação fundiária e no abocanhamento da massa de mais valia global a partir da renda da terra. Tal base da formação territorial brasileira se realiza no duplo caráter da terra como reserva de valor e como reserva patrimonial, fundamentando o rentismo à brasileira no qual a força motriz do capitalismo brasileiro não se encontra na produção, mas sim, na renda (PRIETO, 2018). Além disso, se repôs na formação territorial a grilagem como um legado fundamental que produz a suposta legalidade da propriedade privada capitalista da terra através de um conjunto amplo de expedientes de ilegalidades esfacelando-se, a partir do aparelho de Estado capitalista, as fronteiras jurídicas, e também teóricas do dualismo, de noções como legal/ilegal; modernidade/atraso e formal/informal.

Em meio a essa verdadeira forma-conteúdo de reprodução das classes dominantes no Brasil, os grandes proprietários de terra estavam particularmente interessados em que o processo de reconversão liberal do regime militar na segunda metade da década de 1980 mantivesse o pacto social, político e econômico central da formação territorial brasileira assentado no latifúndio e no capitalismo rentista como condição, meio e produto de seu poder político e fonte de renda, riqueza, poder e patrimônio. A questão da reforma agrária, as organizações políticas de luta pela terra e pelo território no campo e a reprodução social do campesinato e dos povos indígenas eram os inimigos centrais a serem combatidos.

Fundamental ressaltar que o governo Sarney (1985-1990) se concretizou como expressão acabada desse pacto territorial de classe exitoso no controle da transição política no Brasil. Codato (2005) propõe que nos recordemos das palavras de ordem da Aliança Democrática2: "conciliação" e "pacto social", lemas que demonstram que esse arranjo

\footnotetext{
${ }^{2}$ A Aliança Democrática foi um pacto político-ideológico capitaneado pelo PMDB (nova nomenclatura do MDB, o partido de "oposição" autorizado pelo governo ditatorial) e pela Frente Liberal (posteriormente PFL, grupo de dissidentes políticos da ARENA, o partido de governo durante a ditadura) para tentar eleger o presidente nas eleições indiretas de 1985. Tal pacto produziu a chapa Tancredo Neves (presidente) e José Sarney (vice-presidente) em disputa com a candidatura de Paulo Maluf, escolhido do general-presidente Figueiredo indicado para concorrer à presidência pelo PDS (a nova nomenclatura da ARENA). Com o adoecimento e posterior morte de Tancredo, Sarney foi conduzido à presidência da República em 15 de março de 1985 (CODATO, 2005). Sarney, o primeiro presidente civil depois de 21 anos, foi ativo continuador da lenta transição conservadora da ditadura civil-militar brasileira. Esse pacto mais do que apenas um arranjo eleitoral evidenciava uma tentativa de saída consensuada entre as elites e a produção de um novo bloco de poder político entre frações de classe no momento de transição para a democracia no Brasil.
} 
conseguiu neutralizar (ao menos parcialmente), tanto os ensaios de oposição ao regime ditatorial surgidos na conjuntura 1978-1980 (greves operárias, lutas pela terra e movimentos sociais de base), quanto a campanha pelas eleições diretas para a Presidência da República, em 1984. O resultado, nos termos de Codato (2005), foi o aperfeiçoamento de um regime antipopular, conservador e conciliatório ${ }^{3}$.

O Governo Sarney, produto desse arranjo e dessas negociações de poder das elites, fez o esperado por tais frações de classe: conciliou e pactuou auxiliando com as medidas políticas implementadas os blocos capitalistas a se reproduzirem economicamente. Em contradição aparente, no entanto, estabeleceu como um de seus projetos prioritários a reforma agrária ${ }^{4}$. Nesse contexto foi produzido o I Plano Nacional de Reforma Agrária, concretizado no Decreto $\mathrm{n}^{\circ} 91.766$ de 10 de outubro de 1985, que deveria ser aplicado pelo Ministério para o Desenvolvimento e a Reforma Agrária (MIRAD) em conjunto com o INCRA (BRASIL, 1985).

A proposta do I PNRA foi divulgada durante o IV Congresso Nacional dos Trabalhadores Rurais, em maio de 1985, coordenado pela Contag, o que acenava tendencialmente para novas formas de condução da reforma agrária e da política no campo brasileiro (GOMES DA SILVA, 1996). José Gomes da Silva, um dos redatores do Estatuto da Terra de 1964 e um dos fundadores da Associação Brasileira de Reforma Agrária (ABRA), foi escolhido como presidente do INCRA e esteve a frente dos chamados 17 grupos de ação, que contavam com a participação de mais de cem técnicos de todas as regiões do Brasil e que tinham o desafio de esboçar uma proposta de reforma agrária (GOMES DA SILVA, 1996).

De acordo com Mendonça (2010), a proposta apresentada no Congresso da Contag veiculava importantes instrumentos para a efetivação da reforma agrária, sendo o principal deles, fundamental para a obtenção de terras, a implementação de fato da figura jurídica da desapropriação por interesse social, que consiste no direito do Estado (a partir da Constituição de 1988, no entendimento desse artigo, em obrigação estatal) de desapropriar terras que não

\footnotetext{
${ }^{3}$ Rosa Luxemburg (2009) já afirmava que a conciliação de classe envolve sempre um alijamento das classes sociais subalternizadas dos supostos benefícios da pactuação. Os proletários são alvos da superexploração para a manutenção das bases de sustentação do capitalismo e os camponeses sujeitados na extração da renda camponesa. O lucro extraordinário e a drenagem de renda fundiária permaneceriam intactos no arranjo conciliatório entre as frações de classe burguesa, mesmo que proletários e/ou camponeses fossem aderentes (subalternos) ao pacto das elites.

${ }^{4}$ De acordo com Oliveira (2001, p. 200) além da pressão social dos movimentos sociais, a Igreja Católica cumpriu um papel importante nesse processo: “como a pressão social vinha aumentando desde o final dos anos 70 e início dos 80, o governo da Nova República aceitou a elaboração do $1^{\circ}$ PNRA. Durante a visita que Tancredo Neves fez ao Vaticano, inclusive, a única coisa que o Papa lhe pediu foi a realização da reforma agrária. Por esse motivo, Nelson Ribeiro, ligado à Igreja, foi o primeiro ministro da reforma agrária”.
}

$\begin{array}{lll}\text { Prieto, } 2019 & \text { ISSN 0104-5490 }\end{array}$


cumprissem sua função social. A título de exemplo, a desapropriação de terras improdutivas, que atingia diretamente uma das facetas do rentismo - a utilização da terra para fins de especulação.

A proposta instituía também, retomando as perspectivas do Estatuto da Terra, o pagamento de títulos da dívida agrária (TDA) como forma de indenização para as desapropriações, sendo que o pagamento em dinheiro só se aplicaria para as benfeitorias existentes na terra desapropriada (MENDONÇA, 2010). A proposta de reforma agrária, porém, apresentava um elemento que acirrou sobremaneira a luta de classes: o fato de prever que a indenização das terras desapropriadas seria feita com base no valor declarado para fins de cobrança do Imposto Territorial Rural (ITR), o que produziria uma desapropriação tida pelos proprietários de terra como sinônimo de penalização. Mendonça (2010) argumenta que a proposta apresentada pela equipe de José Gomes da Silva ia além, pois, diferentemente da implementação da "reforma agrária dos militares" (OLIVEIRA, 2007), o I PNRA deveria adotar assentamentos em terras devolutas, regularização fundiária de posseiros e desapropriações para a obtenção de terras, prevendo com isso assentar, em 15 anos, 7 milhões de camponeses sem terra de um total estimado à época em 10,5 milhões. No corpus da proposta, segundo Mendonça (2010) estava prevista também a participação das entidades representativas dos camponeses e trabalhadores rurais em todas as fases do processo, inclusive na seleção de áreas prioritárias de reforma agrária e não apenas a efetivação da reforma agrária em áreas de conflito no campo e sem participação popular.

Essa proposta acirrou as lutas de classes no campo brasileiro. O debate sobre o I PNRA fez, inclusive, emergir uma nova entidade patronal ruralista, a $\mathrm{UDR}^{5}$, firmemente interessada no bloqueio de tal proposta. Reuniões, eventos, manifestações, abaixo-assinados, coações e pressões políticas e econômicas se expandiram velozmente: a Confederação Nacional da Agricultura, a Sociedade Rural Brasileira, a Associação Brasileira de Criadores de Zebu, a Agropecuária do Nordeste, a Sociedade Nacional de Agricultura se articularam

\footnotetext{
${ }^{5}$ Segundo Mendonça (2010) e Costa (2013), a UDR se consolidou em junho de 1985, a partir de reuniões realizadas pelos pecuaristas de Goiás (congregando latifundiários de Goiás, São Paulo e Minas Gerais), que se consideravam "marginalizados" do assim chamado processo de "modernização" da agricultura brasileira e discursavam contra o "perigo vermelho" da reforma agrária proposta. Dois sujeitos centrais no momento de formação dessa entidade patronal foram Plínio Junqueira Júnior, pecuarista com propriedades no Pontal do Paranapanema que foi desapropriada no contexto da reforma agrária paulista realizada pelo governo de Franco Montoro mediante atuação efetiva do então secretário estadual de agricultura José Gomes da Silva; e, especialmente, Ronaldo Ramos Caiado, herdeiro de família tradicional (com expressiva representação política desde o Segundo Império) de latifundiários-políticos de Goiás com atuação fundamental nos lobbies ruralistas durante a ANC e, posteriormente como deputado federal (cinco mandatos) e senador da bancada ruralista (autodenominada Frente Nacional Agropecuária) e atualmente como governador de Goiás (DEM-GO).
} 
para criticar (e agir) brutalmente contra a proposta do MIRAD/Incra, a qual foi profundamente alterada restando pouco das proposições iniciais (GOMES DA SILVA, 1996; MENDONÇA, 2010).

Assim, o compromisso discursivo da Aliança Democrática de realização da reforma agrária se esfacelou imediatamente frente aos interesses do rentismo. Mendonça (2010) enfatiza que a discussão dos grandes proprietários de terra resultou numa ampla recomposição de forças intraclasse e demonstrou a necessidade ideológica dos latifundiários de uma postura política clara e de um posicionamento firme de classe frente ao aparelho do Estado brasileiro, desencadeando no discurso da "primazia" da política agrícola sobre a política agrária e na defesa intransigente da propriedade privada capitalista da terra. Além disso, produziu uma reforma agrária de drenagem de recursos públicos para os latifundiários transformando a desapropriação de terras em um negócio capitalista.

O I PNRA aprovado já trazia, no interior de sua redação final (que agradava fortemente os latifundiários reorganizados e ainda mais articulados politicamente), mecanismos jurídicos que eram retrocessos inclusive em relação ao Estatuto da Terra promulgado pelo ditador-presidente Castello Branco (OLIVEIRA, 2007).

Dessa forma, o I PNRA anunciava imediatamente a garantia aos grandes proprietários de terra da sua máxima intocabilidade. Além disso, verificava-se a perspectiva de que seriam beneficiadas pelo programa 1,4 milhão de famílias em pouco mais de 43 milhões de hectares, distribuídos regionalmente da seguinte forma:

Na região Norte seriam assentadas 140.000 famílias em 10.080 .000 ha; na região Nordeste seriam 630.000 famílias em 18.900.000 ha; na região Centro-Oeste seriam 210.000 famílias em 7.560.000 ha; na região Sudeste seriam 280.000 famílias em 4.370 .000 ha; e na região Sul seriam 140.000 famílias em 2.180.000 ha. (OLIVEIRA, 2007, p. 126).

Oliveira (2007) argumenta que, em 1987, na região Norte apenas $18 \%$ das terras previstas tinham sido desapropriadas; no Nordeste, 6\%; no Sudeste, 4\%; no Sul, 10\%; e no Centro-Oeste, $12 \%$. Depois de dois anos, menos de $10 \%$ das metas do I PNRA tinham sido implantadas. O poder politico dos latifundiários, capitaneados pela UDR, demonstrava as pressões de classe no entrave da reforma agrária e da organização política dos grandes proprietários de terra quando os fundamentos do rentismo à brasileira eram ameaçados.

De acordo com o I PNRA, as desapropriações não poderiam ser realizadas em latifúndios produtivos, empresas rurais e em pequenas e médias propriedades (BRASIL, 1985). Entretanto, conforme argumenta Oliveira (2007), orientados pela UDR os 
latifundiários desapropriados ingressaram com interpelações judiciais, buscando embargar as desapropriações e consequentemente o processo de reforma agrária. Em um contexto de altíssima inflação estavam criadas as bases jurídicas para o pagamento de superindenizações por parte do aparelho do Estado brasileiro e simultaneamente a negação do acesso à terra aos camponeses. Esses latifundiários se utilizaram da reforma agrária para abocanhar ainda mais vultosas frações da massa de mais valia global. Para isso se valeram do aumento exponencial do preço das indenizações com inúmeras apelações, embargos e averbações, especulando com a terra e as benfeitorias, em processos que se arrastavam pelo Poder Judiciário e jogando com o processo inflacionário brasileiro, criou-se assim um verdadeiro negócio de TDA (BRASIL, 1999; PRIETO, 2016).

Oliveira (2013) enfatiza que essas apelações junto ao Poder Judiciário foram entravando a implantação do I PNRA e depois de pouco mais de um ano de implantação do Plano, elas já representavam mais de $37 \%$ da área total desapropriada no país, ou seja, mais de 596 mil hectares de terra.

Em 1987, Jader Barbalho assumiu o MIRAD. Após centralizar a reforma agrária no interior do ministério para a condução da política de reforma agrária, que antes cabia ao INCRA. Barbalho extinguiu o órgão, criando em substituição o Instituto Jurídico de Terras Rurais (INTER). Além disso, reduziu o número de famílias que seriam beneficiadas para 1 milhão até 1991 (e não mais 1,4 milhão até 1989), e reduziu também a área a ser desapropriada para 30 milhões de hectares (OLIVEIRA, 2007).

Outra ação a serviço dos grandes proprietários de terra foi a transferência das faixas de terra das rodovias da Amazônia Legal para os governos estaduais, cedendo com isso as terras públicas para o poder local, estratégia esta de reprodução do coronelismo e atualização do agrobanditismo. Torres (2012) argumenta que a indústria da grilagem de terras que se formou no período ditatorial foi reproduzida na transição liberal da ditadura nos processo de revogação dos decretos estaduais na gestão de Barbalho no MIRAD.

Verifica-se segundo dados compilados a partir do INCRA (2014) que, durante o governo Sarney, foram assentadas 50.790 famílias e foram incorporadas 2,6 milhões de hectares de área para a reforma agrária a partir de processos de desapropriação de um total de 69.962 famílias assentadas em 4,3 milhões de hectares de área.

A reforma agrária em seu caráter distributivista e desconcentrador apresentava mais um revés na transição liberal da ditadura para a assim chamada Nova República, visto que a proposta no I PNRA era assentar 1,4 milhão de famílias, em 43 milhões de hectares entre 
1985 e 1989 ficando muito aquém do Plano apresentado. Além disso, as denúncias de grilagem de terra, de desapropriação de terras griladas e da produção de uma verdadeira indústria de superindenizações com TDA foram práticas costumeiras e reveladoras do aparelhamento do Estado na condução da reforma agrária pelos latifundiários (OLIVEIRA, 2007; PRIETO, 2016). E mais, os ruralistas saem mais uma vez fortalecidos politicamente na condução do bloqueio à reforma agrária.

\section{REFORMA AGRÁRIA: A RADICALIDADE CAMPONESA}

Como contraponto ao modelo latifundiário realizado pelo I PNRA e pelas proposições conservadoras dos ruralistas, foram construídas propostas para a realização de profunda reforma agrária para discussão e possível incorporação na ANC.

Exemplo dessa radicalidade camponesa é a proposta-base de reforma agrária apresentada pela Campanha Nacional pela Reforma Agrária $^{6}$ (CNRA) que contava com o apoio da Confederação dos Trabalhadores na Agricultura (CONTAG), do Conselho Indigenista Missionário (CIMI), da Central Única dos Trabalhadores (CUT), do Movimento dos Trabalhadores Rurais Sem Terra (MST), da Comissão Pastoral da Terra (CPT), da Confederação dos Bispos do Brasil (CNBB), da Associação Brasileira de Reforma Agrária (ABRA) e do Instituto Brasileiro de Análises Sociais e Econômicas (IBASE); mais setores progressistas do MIRAD, do INCRA, entre outros. A proposta inicial inquietou o conjunto de contrários à reforma agrária representados pelas entidades patronais dos grandes proprietários de terra, tais como a União Democrática Ruralista (UDR), a Confederação Nacional da Agricultura (CNA), a Organização das Cooperativas Brasileiras (OCB), a Tradição, Família e Propriedade (TFP), a Sociedade Rural Brasileira (SRB) e parte significativa dos deputados constituintes eleitos (PILATTI, 1988; BUTTÓ, 2009; RIBAS, 2011).

As principais resoluções apresentadas pela CNRA centravam-se: i) na subordinação do direito de propriedade a uma obrigação social; ii) no estabelecimento de limite máximo para a propriedade privada; iii) na imissão imediata da União na posse do imóvel desapropriado; iv) na instituição do dispositivo da perda sumária da terra que almejava considerar nula a indenização aos latifundiários devido o comportamento antissocial da

\footnotetext{
${ }^{6}$ De acordo com Quintans e Lopes (2009), a CNRA foi criada em abril de 1983 por associações de defesa da reforma agrária e organizações de trabalhadores rurais. Quintans e Lopes (2009, p. 4) argumentam ainda que "apesar do tema da reforma agrária ter recebido emenda popular com mais de 1,2 milhões de assinaturas, os conservadores através de diferentes manobras e argumentos levaram o tema a cair no "buraco negro", acarretando a aprovação de um texto constitucional muito aquém das propostas defendias pelos setores próreforma agrária".
} 
grande propriedade privada; v) no preço da indenização, caso fosse aplicado, seria determinado pelos impostos (ITR) pagos nos anos antecedentes e; vi) no caráter nacional da propriedade da terra com a instituição de dispositivo constitucional que limitasse a possibilidade para estrangeiros de possuir terras brasileiras para além de uma extensão préestabelecida.

O Partido dos Trabalhadores ${ }^{7}$ (PT) também formulou um anteprojeto para a produção da nova Constituição denominado Muda Brasil! Uma constituição para o desenvolvimento democrático que foi realizada pelo professor e jurista Fabio Konder Comparato no primeiro semestre de 1985 a pedido da Direção Nacional e entregue para a Comissão Executiva Nacional do Partido em fevereiro de $1986^{8}$.

Tal anteprojeto, formulado por Comparato (1986) e ampliado com 148 propostas setoriais, foi defendido pelo PT na ANC como uma direção política para a confecção da Constituição, denominada de $O$ Projeto de Constituição da República Federativa Democrática do Brasil. No texto-base de Comparato (1986), a questão da propriedade privada e da reforma agrária se efetivavam nos seguintes termos:

Regime da propriedade rural

Art. 210 - A terra é capital produtivo, de interesse nacional.

$\S 1^{\circ}-$ É garantido o direito individual de propriedade, na forma do disposto no art. 43, sobre os fundos agrícolas diretamente explorados, nas dimensões necessárias à manutenção do agricultor e sua família, conforme definição dos planos de desenvolvimento agropecuário.

$\S 2^{\circ}$ - Excetuados os casos previstos no parágrafo anterior, a exploração dos fundos agrícolas far-se-á unicamente por meio de cooperativas de pessoas naturais.

$\S 3^{\circ}$ - Para a realização de planos de desenvolvimento agropecuário, a União ou os Estados poderão, ressalvados os casos previstos no paragrafo $1^{\circ}$ deste artigo, expropriar imóveis rurais, mediante o pagamento de indenização em

\footnotetext{
${ }^{7}$ Para a ANC, o PT elegeu dezesseis deputados. O partido criticou a forma com que foi convocada e organizada a ANC. Em outras palavras, a expectativa era de uma Assembleia Constituinte Exclusiva e não a Constituinte congressual, em que deputados e senadores constituintes atuavam paralelamente às atividades normais do Congresso, o que inviabilizava um aprofundamento do processo de transição em que se discutisse amplamente as bases para o estabelecimento da Constituição e se problematizasse o passado recente (e presente) da ditadura civil-militar (GENOÍNO,1987; FUNDAÇÃO PERSEU ABRAMO, 2003).

${ }^{8} \mathrm{O}$ anteprojeto tinha como focos centrais o estabelecimento da origem popular do poder, o reconhecimento da soberania popular, a ampliação da esfera da iniciativa popular, o processo planejado de transformação global das estruturas socioeconômicas, a planificação de uma democratização substancial da sociedade e a efetiva aplicação na sociedade das normas constitucionais. Para mais informações sobre o transformismo do PT, seu processo de sustentação da ordem capitalista e suas metamorfoses para a produção de uma esquerda rentista, ver: Coelho (2005), Iasi (2006), Garcia (2008), Secco (2010) e Prieto (2016).
} 
dinheiro ou títulos da dívida pública, até o montante do valor cadastral do imóvel para fins tributários.

$\S 4^{\circ}$ - Para reprimir a concentração abusiva da propriedade de terras incultas, a lei federal regulará, em processo contraditório, a expropriação sem indenização.

$\S 5^{\circ}$ - Salvo para a execução de planos de desenvolvimento agropecuário, é vedada a apropriação privada de terras devolutas, bem como a alienação ou concessão de terras públicas com área superior a quinhentos hectares. (COMPARATO, 1986, p. 141)

Na reunião ampliada do Diretório Nacional do PT, realizada nos dias 11 e 12 de abril de 1987 em Cajamar (SP), Garcia (1987) relatava a discussão do anteprojeto de Constituição proposto. No que tange à questão da propriedade no campo e na cidade, foi defendida na reunião a necessidade de articulação do anteprojeto com os dispositivos propostos no Documento Preliminar da Campanha Nacional pela Reforma Agrária (CNRA). De acordo com Garcia (1987), a Direção Nacional estabeleceu uma análise de que a Constituição deveria proteger somente a propriedade que cumprisse sua função social, estabelecendo-se objetivamente mecanismos constitucionais de desconcentração fundiária que iriam da desapropriação à expropriação das propriedades que não a cumprem.

Nota-se que ao longo do ano de 1987 ocorreram algumas vitórias iniciais, e apenas parciais, no encaminhamento de determinadas propostas acerca do tema da reforma agrária na ANC, tal como o primeiro substitutivo do então relator da Constituinte Bernardo Cabral (PMDB-AM) condicionando o direito de propriedade rural ao cumprimento de sua função social (PILATTI, 1988; MENDONÇA, 2010). Todavia, ao final desse mesmo ano, se organizou como resposta um bloco suprapartidário conservador solidificado no denominado Centro Democrático, e popularmente chamado de Centrão, que se mostrou relativamente coeso dando demonstrações de força política para implementar modificações em plenário (alterando no meio do processo de elaboração da Constituição, o regimento da ANC) e passar por cima das decisões que se referiam a artigos, emendas, parágrafos e alíneas produzidos sob perspectiva progressista. No que se refere, especialmente, à pauta da reforma agrária, tais como as limitações da extensão da propriedade privada, a possibilidade de realização de desapropriação de terras em propriedade produtiva e a punição dos latifundiários improdutivos, o Centrão foi especialmente organizado para angariar os votos necessários para a vitória nos escrutínios em favor dos ruralistas. 
Gomes da Silva (1989) enfatizou que a articulação política dos conservadores materializada especialmente nas intervenções políticas da União Democrática Ruralista ${ }^{9}$, na figura do latifundiário Ronaldo Caiado, nas ações do presidente José Sarney e de organizações militares (inclusive do ex-ditador-presidente João Figueiredo) consolidou na ANC o Centrão, grupo de 311 deputados constituintes, com o intuito militante de brecar o máximo possível, se não totalmente, incisos constitucionais que contrariassem os principais interesses dos grupos econômicos capitalistas (empresariado e industriais, sobretudo), das Forças Armadas e dos ruralistas.

\section{CENTRÃO, RURALISTAS E O PODER DO LATIFÚNDIO}

Formado primordialmente por congressistas do PMDB, PFL, PTB, PDS e alguns partidos menores, o Centrão representou um papel classista central na derrota de pontos fundamentais para a efetivação da reforma agrária no Brasil. É interessante constatar que, no que tange à questão agrária, para além da importante pressão política exercida pelas entidades patronais ruralistas (tal como a UDR), o próprio perfil político dos congressistas revelava o poder dos latifundiários dentro da ANC. Segundo Sarmento (2009, p. 15):

$37,7 \%$ deles recebiam a maior parte da sua renda do capital (empresários e investidores), 24,9\% de funções na administração e gestão de empresas, $36,3 \%$ de trabalhos de "colarinho branco" na iniciativa privada ou na Administração Pública, e apenas 1,1\% (6 constituintes) eram trabalhadores manuais.

Desdobrando-se especificamente as classes dominantes, Sarmento (2009) verificou que havia predominância dos proprietários de terra $(43,1 \%)$, seguidos daqueles advindos do capital financeiro/bancário $(22,7 \%)$, setores industriais $(11,8 \%)$, comércio e serviços $(10,9 \%)$, mídia $(7,6 \%)$ e outros (3,9\%). Buttó (2009) enfatiza que em números absolutos, 90 constituintes apresentavam rendimentos ligados diretamente à agricultura capitalista, o que

\footnotetext{
${ }^{9}$ Ronaldo Caiado era presidente da UDR à época e tornou-se um articulador central contra a reforma agrária na Constituinte. A reportagem da revista Veja de 18 de junho de 1986 denominada "O trator da direita", em capa que tinha como manchete "A força da UDR", enfatizou que Caiado era: "um jovem senhor goiano, médico e fazendeiro, descendente de uma oligarquia de políticos e latifundiários, ganhou projeção no país como líder de uma classe, a dos produtores rurais, geralmente mais inclinada a ouvir conselhos de gente mais velha. Aos 36 anos, Ronaldo Caiado, um homem de ternos bem cortados e um sorriso permanente que dissimula a insistência com que pode debruçar-se sobre uma questão qualquer, desloca-se pelo Brasil afora em jatos de carreira ou em monomotores emprestados por fazendeiros para pregar a seus colegas de classe. Ele fala de uma coisa simples: a necessidade, para os produtores rurais, de se unirem em torno da defesa de suas terras que julga ameaçadas. Caiado é hoje o cabeça de uma entidade chamada União Democrática Ruralista, a UDR, sintomaticamente nascida logo que o país tomou conhecimento, há pouco mais de um ano, dos primeiros estudos do governo para se promover uma redistribuição do solo nacional de forma a dar fatias de terra às 10 milhões de famílias de lavradores que não dispõem de um pedaço de chão do qual tirar seu sustento" (VEJA, 1986, p. 36).
} 
representava 16,5\% dos congressistas. Costa (2013) argumenta que os parlamentares ruralistas associam expressivo patrimônio fundiário, capital e poder, todavia enfatiza também que para o entendimento mais aprofundado do ruralismo em sua faceta política, deve-se relacionar sua área de atuação profissional com a declaração de bens dos congressistas a fim de verificar as bases econômicas dos seus rendimentos. E mais, há ainda os vínculos indiretos com a agricultura desses parlamentares, que são mediados por relações ideológicas com o ruralismo e que efetivam um posicionamento político latifundiário, tais como: a tradição oligárquica da família, as relações de parentesco para a reprodução da renda, patrimônio e poder familiar, a ação reiterada de tomadas de decisão ligada à classe dos grandes proprietários de terra devido ao compartilhamento ideológico de valores, visões de mundo e trajetórias de vida.

Ademais, a UDR, sob liderança de Ronaldo Caiado, realizava incisivo lobby junto à ANC com a organização política de uma frente ampla de aliança de classes na qualidade de porta-voz informal dos ruralistas (MENDONÇA, 2010). Mendonça (2010) enfatizou ainda que a UDR articulou a Campanha de Valorização do Voto a fim de eleger o máximo de constituintes ligados aos interesses dos grandes proprietários de terra com leilões de gados para financiamento das campanhas e reuniões que indicassem os candidatos mais aptos a representar os interesses dos grandes proprietários de terra. Apesar de explicitamente apenas o deputado constituinte e um dos principais líderes do Centrão, Roberto Cardoso Alves (PMDB-SP), admitir publicamente o apoio político e financeiro da UDR, Mendonça (2010) avalia que 60 deputados contaram com o apoio da entidade patronal dos latifundiários reiterando as práticas clientelistas estruturais do sistema político brasileiro. Destaca-se também conforme apontado por Dreifuss (1989), Bruno (2002) e Mendonça (2010) que a UDR estabeleceu sua estratégia de ação política na tentativa de direção de uma frente de capitalistas urbanos e agrários para influir nas decisões dos congressistas constituintes, o que gerou atritos intraclasse tanto entre os próprios ruralistas incomodados com as práticas ainda mais violentas e autoritárias da UDR, quanto pelos industriais e banqueiros.

Para além dessa faceta supostamente democrática e moderna de lobby, influência e financiamento, a UDR agia com outras táticas de pressão política de intimidação e truculência. Tais ações se concretizam, por exemplo, na facilitação de importação de armamentos para a formação de milícias no campo como resistência armada à reforma agrária do I PNRA do governo Sarney e às ocupações de terra sob o argumento de legítima defesa da propriedade privada e dos latifundiários (MENDONÇA, 2010). Ronaldo Caiado chegou, 
inclusive, a afirmar que havia "uma guerra no campo" e defendeu "a inevitabilidade da violência" contra os camponeses (BRUNO, 1996). A UDR utilizava também táticas de chantagem como a campanha visando o desabastecimento de carne em reação aos decretos de desapropriação para reforma agrária com ameaças no segundo semestre de 1986 de realização de um levante nacional contra o processo de redistribuição fundiária na assim chamada crise do boi gordo (MENDONÇA, 2010) .

A preocupação com o modelo de reforma agrária que seria construída na $\mathrm{ANC}$ e a defesa dos interesses ruralistas se torna ainda mais evidente, quando observamos a situação concreta do aumento da concentração fundiária pela ditadura civil-militar que se explicita na análise da Tabela 1. Constata-se, de acordo com os dados dos Censo Agropecuários de 1975, 1980 e 1985, o aumento vertiginoso da concentração de terras. Nos dez anos compreendidos pela tabela abaixo, demonstra-se o caráter oligárquico da estrutura fundiária com incremento da área ocupada pelos 5\% maiores estabelecimentos rurais de 222 milhões de hectares para mais de 260 milhões de hectares, enquanto a área ocupado pelos 50\% menores manteve-se em cerca de 8 milhões de hectares.

TABELA 1: Estrutura fundiária brasileira entre 1975 e 1985

\begin{tabular}{|l|l|l|l|}
\hline & \multicolumn{1}{|c|}{$\mathbf{1 9 7 5}$} & \multicolumn{1}{|c|}{$\mathbf{1 9 8 0}$} & \multicolumn{1}{|c|}{} \\
\hline Milhões de estabelecimentos com declaração de área & 5,0 & 5,2 & 5,8 \\
\hline Área total (milhões de ha) & 323,1 & 369,6 & 376,3 \\
\hline Área ocupada pelos 5\% maiores (milhões de ha) & 222,0 & 257,6 & 260,4 \\
\hline Área ocupada pelos 50\% menores (milhões de ha) & 8,1 & 8,9 & 8,3 \\
\hline
\end{tabular}

Fonte: Partido dos Trabalhadores, [1989b] 2016, p. 4 organizado por Rodolfo Hoffmann a partir dos Censos Agropecuários de 1975,1980 e 1985

O título da tabela acima que consta no Caderno Temático Questão Agrária do Programa de Ação de Governo (PAG) produzido pelo Partido dos Trabalhadores para as eleições presidenciais de 1989 se encerrava na questão dialética: “Como se formou no Brasil essa estranha combinação entre atraso e avanço?” e revelava, metonimicamente, as inquietações petistas de antanho sobre o campo brasileiro, fundamentadas nas firmes proposições anti-latifundiárias, em defesa da reforma agrária e de um modelo de produção agrária democrático e popular. A monstruosa concentração de terras era interpretada como uma das principais e mais urgentes problemáticas brasileiras ${ }^{10}$. Esse posicionamento radical

\footnotetext{
${ }^{10}$ Nos termos do Caderno Temático Questão Agrária de 1989: "tanto os dados oficiais do governo como os da Comissão Pastoral da Terra (CPT) demonstram um quadro de violência generalizada: a cada ano, mais de meio Prieto, 2019 ISSN 0104-5490 54
} 
se efetiva como resposta política às derrotas no que tange à questão agrária na ANC (PRIETO, 2016).

Na avaliação teórica e política do Partido dos Trabalhadores, outrora defensor de uma reforma agrária radical, sobre os dados sistematizados:

nos censos de 1975, 1980 e 1985, aumenta a área total cadastrada, mas decresce de $2,5 \%$ para $2,2 \%$ a participação relativa dos $50 \%$ menores estabelecimentos rurais. No outro extremo, mantém-se o patamar de quase $70 \%$ de área apropriada pelos 5\% maiores estabelecimentos. Portanto, as novas terras continuam a ser apropriadas prioritariamente pelos grandes proprietários. Vê-se também que no período 1980/85 o número de propriedades cresceu mais do que a área total, indicando um processo de redivisão e possivelmente uma "minifundização" das pequenas propriedades produtivas. Em 1986, o Ministério da Reforma e Desenvolvimento Agrário (Mirad) divulgou novos dados, pelos quais se pode calcular que os 70 maiores latifúndios do país ocupam 6,7\% da área total. Continua o processo de concentração. (PARTIDO DOS TRABALHADORES, [1989b] 2016, p. 4)

Fundamental destacar que os conflitos no campo estão intimamente vinculados com a concentração fundiária. Na expressão veiculada pela Folha de São Paulo em 1987 e retomada por José Gomes da Silva (1989) era a "briga dos sem-terra contra os com-balas". Os dados dos conflitos agrários registrados pela CPT, e contidos na Tabela 2, revelam que entre 19851988 apesar da diminuição de assassinatos no campo, o período registrou estatísticas que revelam a violência estrutural do campo. De 1985 à 1988, em todos os anos ao menos 400 mil pessoas estiveram envolvidas em conflitos fundiários, regularmente mais de noventa assassinatos foram perpetrados por ano, mais de 580 conflitos de terra foram realizados anualmente e ao menos 9,5 milhões de hectares estiveram em disputa no período.

milhão de brasileiros se envolvem em conflitos no campo. É também uma violência seletiva: suas principais vítimas são dirigentes sindicais, líderes comunitários, agentes pastorais e advogados, como os nossos companheiros Wilson Pinheiro, Benezinho, Margarida Alves, Eloy Ferreira da Silva, Nativo da Natividade, Roseli Correa da Silva, Raimundo (Gringo) Ferreira Lima, Sebastião Rosa da Paz, Angelo Kretã, Marçal TupãY, Chico Mendes, Eugênio Lyra, os deputados Paulo Fontelles (PCdoB) e João Carlos Batista (PSB), os padres Josimo Tavares e Ezequiel Ramim e muitos outros" (PARTIDO DOS TRABALHADORES, [1989b] 2016, p. 30). 
Revista de Geografia (Recife) V. 36, No. 2, 2019 - ISSN: 2238-6211

TABELA 2: Conflitos no campo entre 1985 e 1988

\begin{tabular}{|c|c|c|c|c|}
\hline CONFLITOS DE TERRA & 1985 & 1986 & 1987 & 1988 \\
\hline Conflitos em curso & 636 & 634 & 582 & 621 \\
\hline Pessoas envolvidas & 405.456 & 594.448 & 667.177 & 403.733 \\
\hline Hectares em disputa & 9.557 .902 & 12.615 .947 & 17.633 .879 & 19.973 .897 \\
\hline Número de assassinatos & 125 & 105 & 109 & 93 \\
\hline CONFLITOS TRABALHISTAS & 1985 & 1986 & 1987 & 1988 \\
\hline Conflitos em curso & 76 & 95 & 109 & 59 \\
\hline Pessoas envolvidas & 159.185 & 203.521 & 317.406 & 283.780 \\
\hline Hectares em disputa & - & - & 303.800 & 164.400 \\
\hline Número de assassinatos & 14 & 17 & 24 & 9 \\
\hline TOTAL & 1985 & 1986 & 1987 & 1988 \\
\hline Conflitos em curso & 712 & 729 & 691 & 680 \\
\hline Pessoas envolvidas & 564.641 & 797.969 & 984.583 & 687.513 \\
\hline Hectares em disputa & 9.557 .902 & 12.615 .947 & 17.937 .679 & 20.138 .297 \\
\hline Número de assassinatos & 139 & 122 & 133 & 102 \\
\hline
\end{tabular}

Fonte: Partido dos Trabalhadores, [1989b] 2016, p. 30 organizado a partir dos dados da Comissão Pastoral da Terra/ Conflitos no campo - 1988.

A impunidade dos latifundiários nas decisões tomadas pelo Poder Judiciário, as organizações ruralistas e suas milícias privadas e o governo Sarney são apontados como os principais responsáveis pela manutenção dos conflitos (e da luta de classes no campo) conforme ressaltam Bruno (2002) e Oliveira (2007).

Diante disso, a miséria de parte dos camponeses, a ausência de políticas efetivas para uma reforma agrária estrutural e anti-latifundiária e a permanência de milhões de camponeses sem terras eram o resultado de uma concentração fundiária brutal mediada pelo Estado capitalista e pela violência com a permissividade de reprodução da grilagem de terras (PEREIRA, 1988; PARTIDO DOS TRABALHADORES, 1989a). A prova cabal se evidenciava a partir das monstruosas extensões dos latifúndios de propriedade de empresas estrangeiras e nacionais muitas delas ligadas ao empresariado financeiro, industrial e urbano, conforme demonstra a Tabela 3: 
TABELA 3: Empresas industriais e financeiras proprietárias de terra na década de 1980

\begin{tabular}{|l|l|l|}
\hline Nome & Situação & Área (ha) \\
\hline Manasa/Cifec & Estrangeiro & 4.160 .000 \\
\hline Aplub & Financeiro & 2.279 .000 \\
\hline Grupo Antunes-Caemi & Nacional & 2.240 .000 \\
\hline Grupo Bradesco & Financeiro & 893.000 \\
\hline Grupo Klabin & Nacional & 523.000 \\
\hline Grupo Votorantin & Nacional & 498.000 \\
\hline Eni & Estrangeiro & 492.000 \\
\hline Grupo Ometto & Nacional & 439.000 \\
\hline Grupo Calcestruzzi & Estrangeiro & 368.000 \\
\hline Belgo-mineira & Estrangeiro & 288.000 \\
\hline Bamerindus & Financeiro & 254.000 \\
\hline Grupo Bueno-Vidigal & Financeiro & 241.000 \\
\hline Grupo Camargo-Correa & Nacional & 202.000 \\
\hline Grupo Monteiro Aranha & Nacional & 190.000 \\
\hline Grupo Dedini & Nacional & 180.000 \\
\hline Grupo Andrade Gutierrez & Nacional & 168.000 \\
\hline BCN & Financeiro & 144.000 \\
\hline Grupo Itamarati & Financeiro & 132.000 \\
\hline Safra & Financeiro & 108.000 \\
\hline Itaú & Financeiro & 107.000 \\
\hline
\end{tabular}

Fonte: Partido dos Trabalhadores, [1989b] 2016, p. 9 a partir de dados organizados pelos Instituto de Estudos SócioEconômicos (INESC).

Nesse sentido, essas empresas industriais e financeiras que eram também proprietárias de terra a utilizavam para fins especulativos na efetivação da terra como renda patrimonial visto que $80 \%$ eram improdutivas ou apresentavam baixíssimo grau de utilização (OLIVEIRA, 1991). Os ruralistas temiam que a ANC referendasse a instituição de medidas constitucionais que aventassem, por exemplo, o confisco de terras improdutivas, a expropriação de terras com indícios de grilagem ou de expropriação de terras devolutas superiores aos definidos pelas Constituições predecessoras.

Tendo em vista pressionar os trabalhos dos congressistas constituintes, a UDR patrocinou um conjunto de marchas para influir nas votações decisivas da Constituinte, tais como a Marcha dos Produtores à Brasília em julho de 1987 e a reunião da Frente Ampla da Agropecuária Brasileira (FAAB) na capital federal com cerca de 20 mil pessoas em fevereiro de 1987. A UDR também realizou, em março de 1987, manifestações em mais de 100 cidades baseadas na estratégia de impedir o acesso às agências bancárias como forma de pressão e 
chantagem política. O objetivo da entidade era angariar apoiadores da população insatisfeita com a política econômica do governo Sarney para adesão as pautas da UDR, tais como combate à reforma agrária, perseguição/combate/criminalização aos movimentos sociais e a defesa da propriedade privada capitalista da terra na ANC (MENDONÇA, 2010).

A UDR também praticou a tática de criar pânico anticomunista (BARBOSA, 2018). Barbosa (2018) demonstra, que em agosto de 1987, o PCdoB acusou a entidade patronal de ter planejado a distribuição de panfleto falsamente assinado pelo partido, que retratava o avanço do comunismo no Brasil e a suposta ameaça de expulsão da Igreja e dos latifundiários do território nacional quando o novo regime (comunista) fosse estabelecido.

A TFP também cumpriu papel fundamental. A TFP distribuiu a todos os componentes da Subcomissão da Política Agrícola e Fundiária e da Reforma Agrária da ANC suas obras sobre a questão agrária (RIBAS, 2011). Conforme uma delas, denominada de Reforma Agrária: terra prometida, favela rural ou kolkhozes, um parecer produzido por Atílio Guilherme Faoro, integrante da TFP, contra a reforma agrária, afirmava que a reforma agrária "prejudica muito mais gravemente ainda os trabalhadores rurais, do que os próprios fazendeiros. Se a estes ela 'mata', àqueles estraçalha!” (RIBAS, 2011).

Bruno (1996) argumenta que iniciados os trabalhos da ANC o que se constatou não foi meramente a ação dos lobbies dos latifundiários nos gabinetes parlamentares e corredores do Congresso Nacional, mas o poder extraparlamentar direcionando as regras e práticas parlamentares. Bruno (1996, p. 80) argumenta:

Nos momentos mais críticos, eram os deputados e não as lideranças ruralistas que faziam fila para solicitar uma audiência com [Ronaldo] Caiado. O "plenarinho da UDR" era a antessala das discussões plenárias. E vários gabinetes, como o de Cunha Bueno [PDS-SP], transformaram-se em "quartel-general dos grandes proprietários de terra". Era Caiado, e não os constituintes, quem escrevia as emendas constitucionais relativas à reforma agrária e suas justificativas, junto com representantes da Organização das Cooperativas do Brasil (OCB), a Sociedade Rural Brasileira (SRB) e a Confederação Nacional da Agricultura.

A UDR conseguiu mobilizar um núcleo duro de parlamentares constituintes de liderança expressiva formado por Roberto Cardoso Alves (PMDB-SP), Alison Paulinelli (PFL-MG), José Egreja (PTB-SP), Luís Eduardo Magalhães (PFL-BA), Gasthone Righi (PTB-SP), Ricardo Fiuza (PFL-PE), José Lourenço (PFL-BA), Arnaldo Rosa Prata (PMDBMG) e se coligou ideologicamente com o assim chamado "grupo da cana", com os evangélicos, com os doze maiores banqueiros e industriais e com parte expressiva das 
multinacionais em atuação no Brasil (BRUNO, 1996). O caminho da derrota da reforma agrária estava sendo preparado com estratégia política, tática de guerra, violência de classe, poder social e muito dinheiro.

\section{ALIANÇA DE CLASSES E REPRODUÇÃO POLÍTICA DOS RURALISTAS NA ANC: FINCANDO AS RAÍZES DO RENTISMO}

O contexto de concentração fundiária, os conflitos no campo envolvendo terra e trabalho e o uso especulativo da terra são fundamentos e produtos da formação territorial brasileira. As ações político-ideológicas do Centrão como expressão do poder de classe dos ruralistas na ANC não estão alheias a esse panorama, muito pelo contrário. Tais ações podem ser observadas em alguns nós-górdios da reprodução da classe dos grandes proprietários de terra acerca da pauta da reforma agrária, da propriedade privada e da desapropriação de terras na Constituinte de 1987-1988.

Segundo os artigos 17 e 33 da Resolução n. 2 do Regimento da ANC, a Constituinte foi planejada para o funcionamento em três fases sucessivas: a primeira deliberativa e de produção dos artigos constitucionais, a segunda, de sistematização dos artigos em um texto único e no final, a fase de ratificação do texto constitucional realizada em dois turnos (BUTTÓ, 2009)

A fase inicial envolveu a divisão em oito comissões temáticas de 63 membros. Essas comissões eram divididas em três subcomissões de 21 membros que deviam deliberar de maneira independente e encaminhar para a comissão temática o anteprojeto aprovado na subcomissão por maioria absoluta (BUTTÓ, 2009).

A questão agrária foi tratada, especialmente na Subcomissão de Política Agrícola, Fundiária e de Reforma Agrária que estava submetida diretamente à Comissão da Ordem Econômica e iniciou suas atividades em 7 de abril de 1987. Já em seu alvorecer foram realizadas conturbadas e acirradas eleições do relator e do presidente da Subcomissão. A relatoria ficou a cargo de Oswaldo Lima Filho (PMDB-PE), o Oswaldinho, que fora ministro da Agricultura do governo de João Goulart e conhecido por distribuir títulos de terra na Zona da Mata de Pernambuco durante a ditadura civil-militar (GOMES DA SILVA, 1989). A presidência ficou a cargo do conservador Edson Lobão (PFL-MA). Lobão, auxiliado pelas ingerências de Ulysses Guimarães, promoveu na deliberação do parecer do relatório da Subcomissão vasto conjunto de expedientes arbitrários: aceitou a possibilidade de uma emenda substitutiva integral produzida pelos ruralistas (e encaminhada pelo deputado Antonio 
Rosa Prata, PMDB-MG) baseando-se não no Regimento da ANC, mas no da Câmara dos Deputados, encaminhou votação da referida emenda tendo como voto de minerva um suplente e não representante titular da Subcomissão, após o súbito desaparecimento, e ainda não explicado fato, do congressista Benedicto Monteiro (PMDB-PA) em episódio decisivo conhecido como “Cadê o Benedicto?”. O parlamentar não participou da tarde/noite de votação do relatório da Subcomissão no dia 23 de maio de 1987 e da emenda substitutiva integral estando em Belém (PA) no momento do escrutínio e retornando às pressas à Brasília em jatinho particular na madrugada da votação. Benedicto Monteiro apresentou diversas versões sobre o desaparecimento ao longo dos anos.

Destaca-se que da galeria do Congresso Nacional entre a tarde/noite do dia 23 de maio e a madrugada do dia 24 de maio de 1987, representantes da UDR atiraram objetos nos constituintes favoráveis à reforma agrária, ocorreram ameaças de morte, tentativas de suborno e verificou-se a presença de armas de fogo portadas por pessoas que entraram no Congresso Nacional sem serem revistadas (GOMES DA SILVA, 1989; BRUNO, 1996; LAPP, 1996).

Os bloqueios à reforma agrária continuaram nas discussões referentes a questão agrária na Comissão de Ordem Econômica. Realizou-se a tentativa de estabelecimento da "função social potencial" da propriedade, que, nos termos da própria emenda, afirmava ser cumprida a função social quando o imóvel "é, ou está em curso de ser, racionalmente aproveitado" (GOMES DA SILVA, 1989, p. 101) impossibilitando por completo qualquer ação de desapropriação de terras e de política de desconcentração fundiária.

Os trabalhos na Comissão de Sistematização liderados pelo congressista Bernardo Cabral (relatórios Cabral 1 e Cabral 2) foram amplamente criticados seja por sua extensão, seu caráter conciliatório e pelas acusações de retrocesso tanto pela direita, quanto pela esquerda (MAIA; OLIVEIRA, 2017). Os conservadores haviam imposto diversas derrotas à reforma agrária na Comissão de Ordem Econômica, entretanto a proposta do relatório da Constituinte apresentava aspectos que incomodavam os ruralistas, tais como a questão da função social da propriedade e a imissão da posse.

A formação da coalizão de classe mediando setores do centro e da direita se fortaleceu e se articulou na ANC, especialmente quando os trabalhos da Sistematização entraram em sua etapa decisiva (sendo a reforma agrária pauta central para a articulação conservadora), qual seja: a votação do projeto de Constituição (FAORO, 2018; NOGUEIRA, 2010) . A função da Comissão da Sistematização era organizar as propostas advindas desses trabalhos setoriais das comissões em um texto coeso que seria levado ao plenário para discussões, mas com um alto 
grau de dificuldade para possíveis alterações, de acordo com o Regime Interno, visto que este não permitia a apresentação de novas emendas. Nogueira (2010, s/p) argumenta:

Os líderes do Centrão elaboraram um projeto de resolução no qual se destacavam dois dispositivos a favor da alteração do Regimento Interno. Um primeiro permitia a elaboração de emendas coletivas, as quais, pelo número de subscrições, poderiam ter preferência automática sobre o projeto da Sistematização. O segundo instituía o destaque para votação em separado (DVS). Pelo DVS, a aprovação de um requerimento impunha, a quem quisesse manter no texto a parte destacada de um projeto antes aprovado, o ônus de conseguir o quórum de maioria absoluta. Em outros termos, um dispositivo do projeto da Sistematização, destacado para votação em separado, precisaria obter 280 votos em plenário para permanecer no texto.

Os artigos que se referem ao direito de propriedade, por exemplo (incisos XXIII à $\mathrm{XXV}$ do artigo $5^{\circ}$ ), quando foram remetidos ao plenário, entraram no assim chamado "buraco negro" da Constituinte. De acordo com o regime interno da ANC, as emendas precisavam de 280 votos, ou seja, de maioria absoluta para sua aprovação. Caso nenhuma das propostas apresentadas em plenário sobre a matéria fosse aprovada, os trabalhos constitucionais seriam paralisados para a apresentação de nova proposta. O buraco negro significava um impasse decisivo na votação do projeto da Constituição (GOMES DA SILVA, 1989).

Dentre as múltiplas questões de divergências nas propostas apresentadas, uma das que gerou mais conflitos no que concerne a reforma agrária e que explicitava os posicionamentos ideológicos era a possibilidade ou não de desapropriação de terras produtivas. Além desse tema, fundamental para a reforma agrária, outro que produzia embates era como se realizaria o pagamento às terras que fossem desapropriadas. A proposta encaminhada pelo Centrão estabelecia inicialmente a indenização em dinheiro nos casos de desapropriação (o que de fato inviabilizava por completo a reforma agrária retomando a prerrogativa da Constituição de 1946), e quando a proposta foi rejeitada na Câmara se produziu no acerto entre os deputados representantes das elites fundiárias a combinação entre indenização em dinheiro para o pagamento das benfeitorias e títulos da dívida pública para o pagamento das terras.

$\mathrm{O}$ arranjo entre deputados conservadores e ruralistas reforçou a indenização como forma de pagamento do Estado de forma prévia e a "justo preço"11. As benfeitorias construídas nos latifúndios deveriam ser liquidadas em dinheiro e a monopolização da terra paga em títulos da dívida agrária. Além disso, conforme constata Barrocal (2013), o decreto de desapropriação assinado pela presidência da República não garantia a posse imediata do

${ }^{11}$ Para um aprofundamento das questões sobre desapropriação e justo preço, ver: Fonseca (2005), Fidelis (2015) e Prieto (2017b). 
terreno aos beneficiários, antes devia ser examinado pelo Poder Judiciário, a quem cabia a palavra final. Pode ser observado que a questão da desapropriação de terras e das indenizações se consubstanciou no artigo 184, a redação final consta da seguinte maneira:

Art. 184. Compete à União desapropriar por interesse social, para fins de reforma agrária, o imóvel rural que não esteja cumprindo sua função social, mediante prévia e justa indenização em títulos da dívida agrária, com cláusula de preservação do valor real, resgatáveis no prazo de até vinte anos, a partir do segundo ano de sua emissão, e cuja utilização será definida em lei.

$\S 1^{\circ}$ As benfeitorias úteis e necessárias serão indenizadas em dinheiro.

$\S 2^{\circ} \mathrm{O}$ decreto que declarar o imóvel como de interesse social, para fins de reforma agrária, autoriza a União a propor a ação de desapropriação.

$\S 3^{\circ}$ Cabe à lei complementar estabelecer procedimento contraditório especial, de rito sumário, para o processo judicial de desapropriação.

$\S 4^{\circ}$ O orçamento fixará anualmente o volume total de títulos da dívida agrária, assim como o montante de recursos para atender ao programa de reforma agrária no exercício.

$\S 5^{\circ}$ São isentas de impostos federais, estaduais e municipais as operações de transferência de imóveis desapropriados para fins de reforma agrária. (BRASIL, 1988, p. 46).

O jurista Carlos Frederico Marés (2003) argumentou que o artigo 184 da Constituição, ao tratar da desapropriação de imóveis rurais que não estejam cumprindo sua função social, deixava claro que a função social era relativa ao bem, ou melhor, à propriedade, e não à terra. Dessa forma, se esclareceram os fundamentos da proteção à propriedade privada presentes no artigo 5, incisos XXII, XXIII e XXIV da Constituição Federal de 1988.

Art. $5^{\circ}$ Todos são iguais perante a lei, sem distinção de qualquer natureza, garantindo-se aos brasileiros e aos estrangeiros residentes no País a inviolabilidade do direito à vida, à liberdade, à igualdade, à segurança e à propriedade, nos termos seguintes:

XXII - é garantido o direito de propriedade;

XXIII - a propriedade atenderá a sua função social;

XXIV - a lei estabelecerá o procedimento para desapropriação por necessidade ou utilidade pública, ou por interesse social, mediante justa e prévia indenização em dinheiro, ressalvados os casos previstos nesta Constituição.

De acordo com Marés (2003) e Baldez (2012), juridicamente a desapropriação é um ato fundamentado pela Constituição Federal de 1988 de aquisição da propriedade pelo Poder Público. A Constituição, a partir do seu artigo 184, dispõe que são passíveis de processo de 
desapropriação para fins de reforma agrária os imóveis rurais que descumprirem a função social da terra. Já o artigo 186 enfatiza que as propriedades devem cumprir simultaneamente quatro aspectos: um aproveitamento racional e adequado relacionado diretamente à produtividade da terra; a utilização apropriada dos recursos naturais disponíveis, conciliada com a preservação da natureza; a consonância com as disposições que regulam as relações de trabalho; e uma exploração que propicie bem estar aos proprietários e aos trabalhadores (BRASIL, 1988). O direito de propriedade se encontra imbricado com a função social no preceito constitucional, portanto não é uma propriedade absoluta. De acordo com Marés (2003, p. 124-125):

A terra que não está aproveitada, tem aproveitamento inadequado, não preserva o meio ambiente, viola as relações trabalhistas ou não gera bem estar, não pode reivindicar proteção do sistema que atribuiu a obrigação descumprida. A propriedade que não cumpre sua função social é uma espécie de coisa de ninguém, desapropriável, mas também ocupável, por quem puder fazê-la útil à sociedade.

Nesse sentido, longe das alcunhas que possam se propugnar em relação à Constituição de 1988 como "cidadã", "plurissocial" ou "Constituição coragem", a Carta Magna promulgada reproduziu o pacto político-territorial da aliança terra-capital baseada em modificação sem alteração e produção de brechas constitucionais para a manutenção de privilégios, dominação patrimonial e poder político ${ }^{12}$. Essa constatação pode ser melhor apresentada a partir da análise do artigo que se refere às propriedades que são passíveis de desapropriação.

Art. 185. São insuscetíveis de desapropriação para fins de reforma agrária: I - a pequena e média propriedade rural, assim definida em lei, desde que seu proprietário não possua outra;

II - a propriedade produtiva.

\footnotetext{
${ }^{12}$ Uma importante objeção à essa interpretação que desenvolvemos, sobretudo em análise do tema do artigo em questão, Marés (2003) constatou que em relação aos direitos indígenas, das populações quilombolas e do meio ambiente a Constituição Federal de 1988 apresentou uma série de avanços. O artigo 68 que dispõe sobre a questão da propriedade de terras de remanescentes de quilombo se estabeleceu assim: "aos remanescentes das comunidades dos quilombos que estejam ocupando suas terras é reconhecida a propriedade definitiva, devendo o Estado emitir-lhes os títulos respectivos" (BRASIL, 1988, p. 50). Sobre a questão das terras indígenas constatase no artigo 231 o seguinte texto: "são reconhecidos aos índios sua organização social, costumes, línguas, crenças e tradições, e os direitos originários sobre as terras que tradicionalmente ocupam, competindo à União demarcá-las, proteger e fazer respeitar todos os seus bens" (BRASIL, 1988, p. 48). Entretanto, sobre esses três pontos, questões quilombolas, indígenas e ambientais, ocorrem profundos combates realizados pela bancada ruralista do Congresso Nacional para modificações na forma de implementação e mesmo alteração constitucional dos direitos adquiridos.
} 
Parágrafo único. A lei garantirá tratamento especial à propriedade produtiva e fixará normas para o cumprimento dos requisitos relativos à sua função social.

De acordo com Medeiros (1994), verifica-se que o conceito de "latifúndio", que marcou todo um conjunto de debate político da questão agrária brasileira, sobretudo do século $\mathrm{XX}$, se tornou uma categoria jurídica através do Estatuto da Terra foi banida do texto constitucional com a intenção política de obscurecer a luta de classes em torno da fixação dos conceitos na Constituição. Além disso, buscava-se realizar uma transformação no léxico político introduzindo-se um conjunto de novos termos com a intenção de esconder velhas práticas.

Pela análise do artigo 185 constata-se que a propriedade produtiva se tornou insuscetível à desapropriação. A interpretação recorrente do Poder Judiciário sobre esse artigo se referenda na interpretação de que mesmo que não cumpra o conjunto de atributos que competem à função social da propriedade, sobre a propriedade produtiva não se aplica a desapropriação. E mais ainda, a Constituição passou a garantir "tratamento especial" à essa forma de propriedade. Na letra constitucional se inscreveu claramente a lógica do favor: o latifúndio que cumpre a lei e que não incorre em infração constitucional deverá ser premiado. Em decorrência desse processo, pode-se observar o quanto a desapropriação não é uma penalidade ao latifúndio, mas sua salvaguarda, visto que aqueles que cumprem a lei recebem privilégios e aqueles que não cumprem são indenizados pelo Estado.

Além disso, Marés (2010) ressaltou que se estabeleceu uma (proposital) confusão jurídica de cunho ideológico ao se proteger de modo absoluto a assim chamada propriedade produtiva, visto que a produtividade não se assentava apenas na produção de mercadorias, mas em um conjunto de requisitos, conforme observaremos no artigo 186 complementar ao artigo 185. Para a definição dos critérios de produtividade rural são utilizados, até hoje, índices de produtividade estabelecidos em 1975, ou seja que atualmente se encontram defasados em mais de 40 anos.

Interessante retomar a pressão dos proprietários de terra e os confrontos de classe nas votações da ANC acerca da questão da possibilidade de desapropriação da propriedade produtiva. Gomes da Silva (1989, p. 181-186) relatou:

Os milhares de donos de terra que lotavam os hotéis de luxo de Brasília concentravam-se durante o dia no Plenário da liderança por onde todos tinham que forçosamente passar para atingir a sala de Mario Covas, local onde estavam acontecendo as reuniões finais. (...) 
O confronto pessoal e direto entre os trabalhadores rurais e os donos de terra ajudava a aumentar a tensão. Para enfrentar os 3.000 terratenentes da UDR, seus "agroboys" e "agrogirls" que haviam ocupado Brasília, a CONTAG conseguiu, à última hora, trazer uma pequena caravana do Estado do Rio de Janeiro, comandada pelo presidente da Federação, Eraldo Lírio de Azevedo, e mais trinta dirigentes sindicais das áreas mais próximas de Goiás e Minas Gerais. Desta vez foram esses trabalhadores que ocupavam o Plenário da Liderança, sob alguns protestos dos funcionários da Casa, mais acostumada a verem ali os bens trajados representantes da UDR.

Verifica-se que bem trajados por fora, mas representando o velho agrobanditismo que buscava resolver na base da bala o que considerava legal e ilegal. Na reunião de 23 de setembro de 1987 acerca das discussões sobre se a propriedade deveria cumprir uma "função social" ou uma "obrigação social", o plenário se encontrava repleto de representantes da UDR. Gomes da Silva (1989) e Ribas (2011) afirmaram que foram apreendidas na galeria do plenário do Congresso Nacional mais de 50 armas, e no final a proposta da "função social" saiu vencedora.

Silva (1989) argumentou que na votação sobre a retirada ou não da insuscetibilidade da desapropriação da propriedade produtiva o resultado foi favorável à retirada, sendo 267 votos a favor, 253 votos contra e 11 abstenções. Os conservadores perderam a votação, mas garantiram a partir da cláusula de maioria absoluta para a aprovação ou retirada de propostas (que tornava necessária a maioria absoluta de 280 votos) a manutenção da proteção absoluta à propriedade privada produtiva. De acordo com Silva (1989, p. 190) “estava sepultada a reforma agrária no Brasil”.

A deputada Irma Passoni (PT-SP) que desenvolveu sua atividade parlamentar nas Subcomissões da Questão Urbana e Transporte e na Subcomissão da Política Agrícola e Fundiária e da Reforma Urbana na ANC acerca da questão da reforma agrária no documento constitucional sistematizado em 1987, afirmava que esta estava

(...) aquém do Estatuto da Terra. Do jeito que está o texto, a Reforma Agrária não acontecerá. $\mathrm{O}$ substitutivo determina 90 dias de prazo para a imissão na posse da área desapropriada, quando o Estatuto da Terra, do governo Costa e Silva, determinava 48 horas. As desapropriações serão feitas através de decretos do Executivo, o que é um absurdo. Na prática, a Reforma Agrária está sendo transformada em mera colonização, com a contribuição da iniciativa privada. Quer dizer, virou negociata. Pelo substitutivo, os agricultores serão confinados em "vilas", como reserva de mão de obra barata para os fazendeiros. Os planos plurianuais de política agrícola não preveem a participação dos trabalhadores rurais. Os grandes latifundiários mantêm seus privilégios em matéria de incentivos sociais. Em 
suma, o substitutivo deixa muito a desejar, embora pelo menos alguns pontos tenham entrado, quando Sarney e a UDR preferiam que não entrasse nada. (PASSONI, 1987, p. 4)

A deputada Benedita da Silva (PT-RJ), que participou da Comissão da Ordem Social, especificamente na Subcomissão dos negros, indígenas, deficientes e minorias, ressaltou, em 1987, que para atingir igualdade étnico-racial efetiva seria "preciso recuperar as terras dos antigos quilombos, dentro de uma verdadeira reforma agrária” (SILVA, 1988, p. 4). Destacase que um dos elementos importantes da constituinte foi justamente o direito ao território dos povos quilombolas.

Entretanto, o conservadorismo das propostas encaminhadas pelo Centrão ${ }^{13}$ produziu, na interpretação do PT e da CNRA, um projeto que seria encaminhado para a votação com poucos avanços sociais e um conjunto de retrocessos.

Na verdade, o texto do Projeto de Constituição, ressalvados alguns poucos aspectos positivos, tem uma estrutura marcantemente conservadora, principalmente na parte referente à Ordem Econômica: a Reforma Agrária e a Reforma Urbana são praticamente inviabilizadas, e a desnacionalização da economia brasileira está presente com muita ênfase. Em relação ao Projeto de Constituição do PT, o Projeto de Constituição da Comissão de Sistematização incorpora um número relativamente pequeno de propostas petistas, com exceção de alguns dispositivos relativos aos Direitos e Garantias do Homem e da Mulher e à Ordem Social. (DALLARI, 1987, p. 7)

O PT encaminhou o voto contrário à proposta do relator Bernardo Cabral (PMDB$\mathrm{AM}$ ) à Constituição Federal (mas assinou o texto final) e apresentou suas razões para tal. A questão agrária foi argumento central para o voto estabelecido pela bancada petista ${ }^{14}$ :

\footnotetext{
${ }^{13}$ De acordo com Pilatti (2013, s/p) "a excessiva duração dos trabalhos da Comissão de Sistematização (aquela que sintetizava e dava uma forma acabada jurídica as propostas), que reunia menos de um sexto dos constituintes, despertou a insatisfação do chamado "baixo clero", insatisfação esta que acabou manipulada pelos líderes conservadores na criação do chamado "Centrão", que alterou o Regimento para permitir que o Plenário apreciasse outro projeto que não o nascido dos trabalhos das subcomissões e comissões temáticas, consolidados pela Comissão de Sistematização num texto mais progressista do que conservador". Pilatti (2013) enfatiza que o Centrão, mesmo com um grande número de deputados, não conseguiu impor um completo conservadorismo nas proposições, e o resultado foi o desencadeamento de um longo processo de negociação durante as votações no Plenário, o que permitiu, de acordo com o autor, preservar parte significativa dos conteúdos progressistas do texto constitucional.

${ }^{14}$ Em balanço sobre a ANC e sobre a Constituição aprovada, o Partido dos Trabalhadores reiterou, à época, seu posicionamento de partida que "almeja o socialismo" e rejeita a "ordem burguesa". Assim, "o PT, como partido que almeja o socialismo, é por natureza um partido contrário à ordem burguesa, sustentáculo do capitalismo. Disso decorre que o PT rejeita a Constituição burguesa que vier a ser promulgada, da mesma forma que a Constituição vigente, a qual, ainda por cima, é fruto de uma ditadura militar; por extensão, o PT rejeita a imensa maioria das leis que constituem a institucionalidade que emana da ordem burguesa capitalista, ordem que o partido justamente procura destruir e, no seu lugar, construir uma sociedade socialista. (PARTIDO DOS TRABALHADORES, 1988, p. 15)
} 
Depois de vários debates com a participação da bancada, o Diretório Nacional decidiu que o PT deveria votar não ao texto global, expressando nosso inconformismo com o seu caráter geral. $\mathrm{O}$ voto não representa a rejeição do PT aos princípios conservadores inscritos em questões fundamentais. Com relação à reforma agrária, a proibição de desapropriar terras "produtivas" (sem definir o que é produtivo) é pior do que estabeleceu o Estatuto da Terra, do regime militar . (PARTIDO DOS TRABALHADORES, 1988, p. 1)

No que se refere ao significado jurídico da função social, conforme já foi argumentado, e o que deve ser cumprido para que esta se efetue, se encontra a seguinte resolução na Constituição Federal:

Art. 186. A função social é cumprida quando a propriedade rural atende, simultaneamente, segundo critérios e graus de exigência estabelecidos em lei, aos seguintes requisitos:

I - aproveitamento racional e adequado; $;$ [Ep:

II - utilização adequada dos recursos naturais disponíveis e preservação do meio ambiente; ;s[e:

III - observância das disposições que regulam as relações de trabalho, ;istep

IV - exploração que favoreça o bem-estar dos proprietários e dos trabalhadores. (BRASIL, 1988, p. 46)

Analisando os requisitos prescritos no artigo 186 da Constituição, demonstra-se que é fundamental para que a propriedade cumpra sua função social e que tenha direito à proteção constitucional a realização simultânea de todos os termos. Assim, baseado nas análise de Bercovici (2003), Marés (2003) e Souza (2007), observa-se que o conjunto de requisitos constitucionais que tornam uma propriedade cumpridora da função social é constituída articuladamente de fundamento econômico (aproveitamento racional e adequado), fundamento ambiental $^{15}$ (utilização adequada dos recursos naturais e preservação do meio ambiente) e fundamento social (observância das normas que regulam as relações de trabalho e exploração que favoreça o bem-estar dos proprietários e trabalhadores). Dessa forma, as propriedades que infrinjam a legislação ambiental e trabalhista e que não cumpram os requisitos de produtividade são passíveis de desapropriação para fins de reforma agrária (MARÉS, 2003; BERCOVICI, 2003; SOUZA, 2007).

Analisando cada um dos requisitos estabelecidos pela Constituição de 1988 pode-se constatar que passados mais de 25 anos de sua promulgação vivencia-se um processo de

${ }^{15} \mathrm{O}$ fundamento ambiental da função social da propriedade deve ser analisado em associação ao artigo 225 da Constituição Federal que versa especificamente sobre as questões ambientais. 
combate e ataque à função social da propriedade no que se refere à reprodução violenta da institucionalização de proteção e absolutização dos interesses da classe dos grandes proprietários de terra e da propriedade privada capitalista.

Acerca das leis agrárias complementares a Constituição Federal conforme enfatizado nos artigos 184, 185 e 186, Marés (2003, p. 115) argumenta que

Quando a Constituição foi escrita (...) os chamados ruralistas, nome gentil dado aos latifundiários, foram construindo dificuldades no texto constitucional para que ele não pudesse ser aplicado. Como não podiam desaprovar claramente o texto cidadão, ardilosa e habilmente introduziram senões, imprecisões e exceções que, contando com a interpretação dos juízes e do próprio Poder Executivo, fariam do texto letra morta, transportando a esperança anunciada na Constituição para o velho enfrentamento diário das classes dominadas, onde a lei sempre é contra. (...) a primeira providência dos latifundiários chamados de ruralistas, foi introduzir um vírus de ineficácia em cada afirmação [constitucional]. Assim, onde a Constituição diz como se cumpre a função social, se lhe acrescenta que haverá de ter uma lei (outra lei, inferior) que estabeleça 'graus e exigências', com isso, dizem os Tribunais, já não se pode aplicar a Constituição sem uma lei menor que comande a sua execução.

Assim, no que se refere ao conjunto de dispositivos constitucionais, verifica-se que se reduz a aspectos eminentemente economicistas nas decisões dos tribunais brasileiros, reproduzindo no Poder Judiciário os bloqueios à desapropriação de terras. E ainda mais, no processo de desapropriação de terras beneficiam-se amplamente os latifundiários com pagamentos exorbitantes de indenização, reproduzem-se processos de legalização da grilagem de terra (e o recebimento de indenizações por terras griladas) e a utilização da terra como reserva de valor e reserva patrimonial (PRIETO, 2016). Ressalta-se que a Constituição permite a apropriação de até 50 hectares de terras públicas:

Art. 191. Aquele que, não sendo proprietário de imóvel rural ou urbano, possua como seu, por cinco anos ininterruptos, sem oposição, área de terra, em zona rural, não superior a cinquenta hectares, tornando-a produtiva por seu trabalho ou de sua família, tendo nela sua moradia, adquirir-lhe-á a propriedade.

Parágrafo único. Os imóveis públicos não serão adquiridos por usucapião. (BRASIL, 1988, p 47).

Com isso, verifica-se, na letra da lei, que a Constituição Federal de 1988 é mais retrógrada que o Estatuto da Terra produzido na ditadura civil-militar, visto que quando se produz, no Brasil, um ordenamento jurídico com a possibilidade real de ser implementado, as elites fundiárias mobilizaram seu conjunto de interesses para os bloqueios às possibilidades de 
rupturas radicais. Uma nota de fechamento das discussões no artigo 51 da Constituição dispõe que

Art. 51. Serão revistos pelo Congresso Nacional, através de Comissão mista, nos três anos a contar da data da promulgação da Constituição, todas as doações, vendas e concessões de terras públicas com área superior a três mil hectares, realizadas no período de $1^{\circ}$ de janeiro de 1962 à 31 de dezembro de 1987.

$\S 1^{\circ}$ No tocante às vendas, a revisão será feita com base exclusivamente no critério de legalidade da operação.

$\S 2^{\circ}$ No caso de concessões e doações, a revisão obedecerá aos critérios de

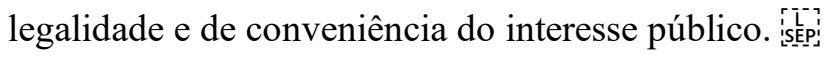

$\S 3^{\circ} \quad$ Nas hipóteses previstas nos parágrafos anteriores, comprovada a ilegalidade, ou havendo interesse público, as terras reverterão ao patrimônio da União, dos Estados, do Distrito Federal ou dos Municípios. (BRASIL, 1988, p. 50)

Devido à imensa apropriação de terras públicas e por pressão dos movimentos sociais e do conjunto de denúncia realizadas, especialmente durante a ditadura civil-militar e nos primeiros anos da "Nova República", se propôs na Constituição Federal este artigo, uma revisão das grilagens legalizadas ao longo do período entre 1962 e 1987 (PRIETO, 2017a). Todavia esse dispositivo constitucional nunca foi posto em prática. Os grandes proprietários de terra demonstram seu poder de classe na realização das leis e no bloqueio à aplicação da lei quando estas se opõem ao pacto político-territorial substanciado no processo, ainda em realização, da formação territorial brasileira.

\section{$* * *$}

O bloqueio à reforma agrária e a luta sistemática dos latifundiários pela sua impossibilidade e/ou realização precária é forma de obstar o acesso à terra pelos camponeses, visto que a terra mesmo sem nenhuma produção, nenhuma benfeitoria, nenhum trabalho humano concretizado pode enriquecer o proprietário. A terra como equivalente de capital, apropriada privadamente em vastas extensões, funciona como renda capitalizada e renda especulativa, e drena vultosa massa de mais valia global extraída do conjunto da sociedade e produz no Brasil uma classe de grandes proprietários de terra, rentistas, que se reproduz cotidianamente como classe capitalista.

Diante disso, a ANC reproduziu juridicamente limitantes e condicionantes ao processo de desconcentração fundiária e foi essencial para organizar os interesses políticos ruralistas 
como expressão central do capitalismo rentista à brasileira na contemporaneidade. Aos camponeses, como historicamente, a luta pela conquista da terra permanece urgente em suas ações diretas de ocupações, nas pressões políticas junto ao aparelho do Estado, ao Poder Judiciário e no firme questionamento cotidiano, a partir de sua recriação como classe incômoda, à aliança de classes entre terra e capital que dirige e verdadeiramente governa o Brasil.

\section{REFERÊNCIAS}

ASSEMBLEIA NACIONAL CONSTITUINTE (1987-1988). Anais da Assembleia Constituinte. Disponível

em: https://www.senado.leg.br/publicacoes/anais/asp/CT_Abertura.asp

BALDEZ, M. Desapropriação. In: CALDART, R. et al. Dicionário de Educação do Campo. Rio de Janeiro: EPSJV; São Paulo: Expressão Popular, 2012, p. 198-203.

BARBOSA, M. História da União Democrática Ruralista (UDR) em Goiás: o epicentro da ação ruralista na Constituinte de 1988. Tese (Doutorado em História) - Instituto de História, Universidade Federal de Uberlândia, Uberlândia, 2018.

BARROCAL, A. Constituição e PMDB seguram reforma agrária. Carta de 1988 completa 25 anos de visão mercantil pró-fazendeiros. Obra do peemedemismo, que enfim recebe a líder ruralista Kátia Abreu. Carta Capital, São Paulo, 5 out. 2013.

BERCOVICI, G. Entre o Estado total e o Estado social: atualidade do debate sobre Direito, Estado e Economia na República de Weimar. Tese (Livre-Docência em Direito Econômico) Faculdade de Direito, Universidade de São Paulo, São Paulo, 2003.

BRASIL. Decreto n. 91.766, de 10 de outubro 1985. Aprova o Plano Nacional de Reforma Agrária - PNRA, e dá outras providências. Disponível em: <http://www2.camara.leg.br/legin/fed/decret/1980-1987/decreto-91766-10-outubro-1985441738-publicacaooriginal-1-pe.html>. Acesso: 22 jan. 2019.

BRASIL. Constituição (1988). Constituição da Republica Federativa do Brasil, de 5 de outubro de 1988. Brasília - DF, 1988.

BRASIL. Ministério de Política Fundiária e da Agricultura Familiar/INCRA. Livro Branco das Superindenizações. Brasília - DF, 1999.

BRASIL. Ministério de Política Fundiária e da Agricultura Familiar/INCRA. Livro Branco da Grilagem. Brasília - DF, 2001.

BRUNO, R. L. Revisitando a UDR: ação política, ideologia e representação. Revista do Instituto de Estudos Brasileiros, São Paulo, v. 40, p. 69-90, 1996.

BRUNO, R. L. O ovo da serpente: monopólio da terra e violência na Nova República. Tese (Doutorado em Ciências Sociais) - Instituto de Filosofia e Ciências Humanas, Universidade Estadual de Campinas, Campinas, 2002. 
BUTTÓ, M. Mecanismos deliberativos na Assembleia Nacional Constituinte: a polarização simbólica da reforma agrária. Dissertação (Mestrado em Ciência Política) Faculdade de Filosofia, Letras e Ciências Humanas, Universidade de São Paulo, São Paulo, 2009.

CODATO, A. Uma história política da transição brasileira: ișpịda ditadura militar à democracia. Revista de Sociologia e Política, Curitiba, n. 25, p. 83-106, nov. 2005.

COELHO, E. Uma esquerda para o capital: crise do marxismo e mudanças nos projetos políticos dos grupos dirigentes do PT (1979-1998). Tese (Doutorado em História) - Instituto de Ciências Humanas e Filosofia, Universidade Federal Fluminense, Niterói, 2005.

COMPARATO, F. K. Muda Brasil: uma Constituição para o desenvolvimento democrático. São Paulo: Brasiliense, 1986.

COSTA, S. H. A questão agrária no Brasil e a bancada ruralista no Congresso Nacional. 2013. Dissertação (Mestrado em Geografia Humana) - Faculdade de Filosofia, Letras e Ciências Humanas, Universidade de São Paulo, São Paulo, 2013.

DALLARI, P. Constituinte segundo tempo, hora de virar o jogo! Boletim Nacional n. 30, São Paulo, ago. 1987, p. 6-7.

DREIFUSS, R. A. O jogo da direita na Nova República. Petrópolis: Vozes, 1989.

FAORO, R. A República em transição: poder e direito no cotidiano da democratização brasileira (1982-1988). Rio de Janeiro: Record, 2018.

FERNANDES, F. O processo constituinte. Brasília: Câmara dos Deputados, Centro de Documentação e Informação, Coordenação de Publicações, 1988

FONSECA, A. Juros compensatórios ou juros de dano: discussão das Súmulas 618, 416, 345 e 164 do STF (exposição de motivos para provocar o cancelamento das súmulas 618, 416, 345 e 164). Brasília, 2005.

FONTES, Virgínia. O Brasil e o capital-imperialismo: teoria e história. 2 ed. Rio de Janeiro: EPSJV/Editora UFRJ, 2010

FUNDAÇÃO PERSEU ABRAMO. Partido dos Trabalhadores: trajetórias. São Paulo: Fundação Perseu Abramo, 2003.

GARCIA, M. A. Nosso Projeto de Constituição. Boletim Nacional, n. 27, São Paulo, mai. 1987, p. 8.

GARCIA, C. Partido dos Trabalhadores: da ruptura com a lógica da diferença à sustentação da ordem. 2008. Tese (Doutorado em História) - Instituto de Ciências Humanas e Filosofia, Universidade Federal Fluminense, Niterói, 2008.

GENOÍNO, J. A Constituinte que não queremos. Boletim Nacional, n. 15, São Paulo, dez. 1985 , p. 3. 
GOMES, M. E. (coord.). A Constituição de 1988, 25 anos - a construção da democracia e liberdade de expressão: o Brasil antes, durante e depois da Constituinte. São Paulo: Instituto Vladimir Herzog, 2013.

GOMES DA SILVA, J. Buraco negro: a reforma agrária na Constituinte. Rio de Janeiro: Paz e Terra, 1989.

GOMES DA SILVA, J. A reforma agrária brasileira na virada do milênio. Campinas: ABRA, 1996.

IANNI, O. A luta pela terra: história social da terra e da luta pela terra numa área da Amazônia. Petrópolis: Vozes, 1979.

IASI, M. As metamorfoses da consciência de classe: o PT entre a negação e o consentimento. São Paulo: Expressão Popular, 2006.

INSTITUTO NACIONAL DE COLONIZAÇÃO E REFORMA AGRÁRIA. Sistema de Informações de Projeto de Reforma Agrária 2014. Ministério do Desenvolvimento Agrário, 2014.

LAPP, N. D. Landing Votes: Political Representation and Land Reform in Latin America. New York: Palgrave Macmillan, 2004.

LUXEMBURG, R. Introduction à l'économie politique - Euvres complètes. Tome I. [1925] Marseille/Toulouse : Agone/Smolny, 2009.

MAIA, G.; OLIVEIRA, L. Três décadas depois: a Assembleia Nacional Constituinte de 1987 e o debate (inconcluso) da reforma agrária no Brasil. Revista Brasileira de Direito, Passo Fundo, vol. 13, n. 2, p. 41-61, Mai.-Ago. 2017

MARÉS, C. F. A função social da terra. Porto Alegre: Sergio Antonio Fabris Editor, 2003.

MARÉS, C. F. Função social da propriedade. In: SONDA, C.; TRAUCZYNSKI, S. C. (org.). Reforma agrária e meio ambiente. Curitiba: ITCG, 2010, p. 181-198.

MARTINS, J. S. O poder do atraso: ensaios de sociologia da história lenta. São Paulo: Hucitec, 1994.

MEDEIROS, L. S. Reforma agrária: concepções, controvérsias e questões. Cadernos Temáticos, Rio de Janeiro, v. 1, n.1, p. 01-64, 1994.

MENDONÇA, S. R. A questão agrária no Brasil: a classe dominante agrária - natureza e comportamento 1964-1990. São Paulo: Expressão Popular, 2010.

NOGUEIRA, A. M. Centrão. In: ABREU, A. A. de et al (coords.). Dicionário HistóricoBiográfico Brasileiro - Pós-1930. Rio de Janeiro: CPDOC, 2010.

OLIVEIRA, A. U. Agricultura camponesa no Brasil. São Paulo: Contexto, 1991.

OLIVEIRA, A. U. A longa marcha do campesinato brasileiro: movimentos sociais, conflitos e Reforma Agrária. Estudos Avançados, IEA/USP São Paulo, v. 15, n.43, p. 185-206, 2001.

OLIVEIRA, A. U. Modo capitalista de produção, agricultura e reforma agrária. São Paulo: FFLCH/LABUR, 2007. 
OLIVEIRA, A. U. A Amazônia e a reforma agrária de novo no banco dos réus. ABRA, São Paulo. 2008.

Disponível em: <http://www4.fct.unesp.br/nera/artigodomes/10artigodomes.pdf> Acesso em: 21 jan. 2019.

OLIVEIRA, A. U. A questão da aquisição de terras por estrangeiros no Brasil - um retorno aos dossiês. AGRÁRIA, São Paulo, n. 12, p. 3-113, 2011 a.

OLIVEIRA, A. U. Os posseiros voltam a assumir o protagonismo da luta camponesa pela terra no Brasil. In: Comissão Pastoral da Terra (org.). Conflitos no Campo Brasil - 2010. Goiânia: CPT, 2011b, v. 1, p. 55-62.

PARTIDO DOS TRABALHADORES (Diretório Nacional). 1988, A posição do PT sobre a nova Constituição. Circular Interna de 7 de agosto de 1988, anexo 2, p. 12-14.

PARTIDO DOS TRABALHADORES. As bases do PAG (Plano de Ação de Governo). [1989a]. Resoluções de Encontros e Congressos \& Programas de Governo. São Paulo: Partido dos Trabalhadores; Fundação Perseu Abramo, 2016. Disponível em: http://csbh.fpabramo.org.br

PARTIDO DOS TRABALHADORES. Brasil Urgente! Lula Presidente! Caderno Temático Questão Agrária. [1989b]. Resoluções de Encontros e Congressos \& Programas de Governo. São Paulo: Partido dos Trabalhadores; Fundação Perseu Abramo, 2016. Disponível em: http://csbh.fpabramo.org.br

PASSONI, I. Houve retrocesso nas desapropriações urbanas. Entrevista. PT na Luta da Constituinte, n. 4, Brasília, 10 out. 1987, p. 4.

PEREIRA, H. Levantados do Chão. Revista Teoria \& Debate, São Paulo, n. 4, 1988.

PILATTI, A. Marchas de uma contramarcha: transição, UDR e Constituinte. 1988. Dissertação (Mestrado em Ciências Jurídicas) - Departamento de Ciências Jurídicas, Pontifícia Universidade Católica do Rio de Janeiro, Rio de Janeiro, 1988.

PILATTI, A. Constituintes, Golpes e Constituições: os caminhos e descaminhos da formação constitucional do Brasil desde o período colonial. In: GOMES, M. E. (coord.). A Constituição de 1988, 25 anos: a construção da democracia e liberdade de expressão - o Brasil antes e depois da Constituinte. São Paulo: Instituto Vladimir Herzog, 2013, p. 26-133.

PRIETO, G. Rentismo à brasileira, uma via de desenvolvimento capitalista: grilagem, produção do capital e formação da propriedade privada da terra. São Paulo, Tese (Doutorado em Geografia Humana) - Faculdade de Filosofia, Letras e Ciências Humanas, Universidade de São Paulo.

PRIETO, G. A aliança entre terra e capital na ditadura brasileira. Mercator. Fortaleza, v. 16, p. 1-14, 2017a.

PRIETO, G. O duplo caráter da desapropriação: a transformação da luta pela terra em negócio capitalista. In: FERREIRA, G. (org). Geografia Agrária em debate. Jundiaí: Paco Editorial, 2017b, p. 51-72. 
PRIETO, G. A problemática da formação nacional: da gênese aos fundamentos da propriedade privada. In: CARLOS, A.F.A. et al. (Org.). Geografia urbana crítica: teoria e método. São Paulo: Contexto, 2018, v. 1, p. 139-154.

QUARTIM DE MORAES, J. Les militaires et les régimes politiques au Brésil de Deodoro à Figueiredo (1889-1979). Thèse de Doctorat d'Etat, Institut d'Études Politiques de Paris, Paris, 1982.

QUINTANS, M; LOPES, A. Judiciário e Constituição Federal de 1988: interpretações sobre o direito à propriedade privada face à Reforma Agrária e ao direito ao território quilombola. Revista IDEAS, v. 4, p. 225-264, 2010.

RIBAS, L. O. UDR E TFP: a força bruta que enterrou a reforma agrária na constituinte de 1987. Em Debate (UFSC), v. 5, 2011.

SAMPAIO, P. A. A participação popular na Constituinte. Boletim Nacional n. 26, São Paulo, abr. 1987, p. 11.

SECCO, L. História do PT - 1978-2010. Cotia: Ateliê, 2011.

SARMENTO, D. A Assembleia Constituinte de 1987/1988 e a experiência Constitucional Brasileira sob a Carta de 1988. Revista de Direito do Estado, Rio de Janeiro, n. 30, p. 9 - 41, 2009.

SHANIN, T. La clase incomoda: sociología política del campesinado en una sociedad en desarrollo (Rusia 1910-1925). Madrid: Alianza Editorial, 1983.

SILVA, B. Cem anos de abolição, e a opressão continua. Entrevista. PT na Luta da Constituinte, n. 7, Brasília, mar. 1988, p. 4.

SOUZA, M. R. Regime jurídico da propriedade produtiva no Direito brasileiro. 2007, Dissertação (Mestrado em Direito) - Universidade Estadual Paulista "Júlio de Mesquita Filho", Franca, 2007.

TORRES, M. Terra privada, vida devoluta: ordenamento fundiário e destinação de terras públicas no oeste do Pará. Tese (Doutorado em Geografia Humana) - Faculdade de Filosofia, Letras e Ciências Humanas, Universidade de São Paulo, São Paulo, 2012.

VEJA. O trator da direita. São Paulo, Ed. Abril, n. 928, 18 jun. 1986. 